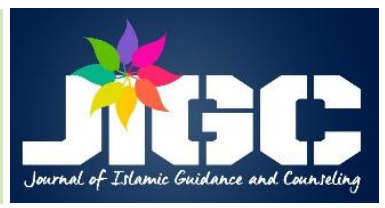

Bimbingan dan Konseling Islam

\title{
Berbagai Strategi Bimbingan Konseling Islam Dalam Menghadapi Peluang Dan Tantangan Revolusi Industri 4.0
} Arif Ainur Rofiq ${ }^{1}$

${ }^{1}$ Fakultas Dakwah dan Komunikasi UIN Sunan Ampel Surabaya, Jawa Timur 60237, Indonesia

\section{InformasiArtikel}

SejarahArtikel:

Diterima Redaksi: 2019-12-30

Revisi Akhir:

DiterbitkanOnline:

\section{Korespondensi}

Telepon:

E-mail: arifainurrofiq@uinsby.ac.id

\begin{abstract}
Abstrak: Bimbingan Konseling Islam sebagai salah satu Profesi yang dapat memberikan bantuan kepada individu yang menghadapi masalah untuk kembali kepada ajaran agama Islam (fitrah), menghadapi peluang dan tantangan di era Revolusi Industri 4.0. Ketika kemudahan informasi teknologi dapat meningkatkan perubahan dan perkembangan pola kehidupan manusia, disisi lain muncul berbagai masalah psiko-sosial dan kesehatan masyarakat (Narkoba, dan sebagainya). Bimbingan Konseling Islam hadir untuk menghadapi peluang dan tantangan, dengan berbagai bentuk peningkatan pelayanan, teknik maupun strategi, yang dapat memberikan solusi pada masalah individu, dan sesuai kebutuhan masyarakat.
\end{abstract}

Kata kunci: Peluang, Tantangan, Strategi, Bimbingan Konseling Islam

Abstract: Islamic Counseling Guidance as a profession that can provide assistance to individuals who face problems to return to the teachings of Islam (fitrah), face opportunities and challenges in the era of the Industrial Revolution 4.0. When the ease of information technology can improve changes and developments in the pattern of human life, on the other hand there are various psycho-social and public health problems (Narcotics, etc.). Islamic Counseling Guidance is present to face opportunities and challenges, with various forms of improving services, techniques and strategies, which can provide solutions to individual problems, and according to community needs.

Keywords: Opportunities, Challenges, Strategies, Islamic Counseling Guidance. 


\section{A. Pendahuluan}

Era Revolusi Industri 4.0 telah banyak membawa perubahan dan perkembangan teknologi dan informasi, kecenderungan ekonomi global, dan perubahan struktur dunia kerja, mempengaruhi peningkatan mutu dan produktivitas manusia terdidik yang mampu berkompetisi dalam berbagai kehidupan. Masyarakat berbasis ilmu pengetahuan merupakan wajah masyarakat dunia masa depan. Peradaban manusia milenial merupakan suatu keniscayaan, maka setiap orang harus dapat menyesuaikan dirinya dengan lingkungan jika tidak ingin mengalami keterasingan. Dunia kerja dan kehidupan menuntut semua orang, baik secara perseorangan maupun organisasi untuk selalu menguasai pengetahuan, wawasan, dan keterampilannya agar bisa tetap eksis dan memiliki ketahanan di dalam dunia global ini. Masyarakat yang tidak menguasai ilmu pengetahuan akan tercecer bahkan menjadi budak dari masyarakat yang menguasai ilmu pengetahuan dan teknologi.

Akan tetapi era revolusi industri 4.0 ini, walau dapat membawa perubahan dan perkembangan teknologi, juga melemahkan sistem sosial ekonomi yang menunjang masyarakat Indonesia, karena mempengaruhi remaja dengan informasi yang negatif dan tidak bisa dipertanggungjawabkan dapat menghancurkan mental generasi muda atau remaja yang akan membangun Bangsa dan Negara karena pertukaran informasi global yang tanpa sekat. Migrasi Internasional dan globalisasi telah mengakibatkan adanya masalahmasalah psiko-sosial dan kesehatan remaja; idiologi sekulerisme, paham radikalisme, penggunaan obat-obatan terlarang (Narkoba), perilaku seks menyimpang (Sex before marriage, Homosex), yang disebabkan oleh gaya hidup diadopsi dari pertukaran informasi yang terintegrasi secara internasional melalui internet (Internet of Things/IoT).

Berdasarkan berbagai masalah yang muncul di era ini, hadirnya Bimbingan Konseling Islam sesuai fungsinya untuk mengembalikan seorang atau individu pada fitrahnya, yang mengalami kesulitan lahir dan batin untuk dapat memahami dirinya dan mampu memecahkan masalah yang dihadapinya sehingga dapat hidup secara harmonis sesuai dengan ketentuan dan petunjuk Allah dan Rasul-Nya demi tercapainya kebahagiaan duniawiah dan ukhrawiah.

Kegiatan Bimbingan Konseling Islam sebagai salah satu upaya untuk membantu individu memperkembangkan diri secara optimal sesuai dengan tahap-tahap perkembangan dan tuntutan lingkungan. Bimbingan Konseling Islam sebagai profesi bantuan diperuntukan bagi individu-individu normal yang sedang menjalani proses perkembangan sesuai dengan tahap-tahap perkembangan agar mencapai perkembangan optimal, kemandirian dan kebahagiaan dalam menjalani berbagai kehidupan. Konseling membantu individu mengaktualisasikan dirinya secara optimal dalam aspek kecerdasan intelektual, kecerdasan emosional, kecerdasan spiritual, kecerdasan sosial, dan kecerdasan kinestetik, sehingga akan dapat diwujudkannya manusia yang berhasil sebagai pribadi mandiri (mahluk individu), sebagai elemen dari sistem 
sosial yang saling berinteraksi dan mendukung satu sama lain (mahluk sosial), dan sebagai pemimpin bagi terwujudnya kehidupan yang lebih baik di muka bumi (mahluk Tuhan).

Bimbingan Konseling Islam(BKI) hadir untuk memenuhi kebutuhan masyarakat akan bantuan peningkatan kualitas hidup melalui layanan kesejahteraan dan kesehatan jiwa yang menggunakan pendekatan religi, dalam hal ini Islam. Di era revolusi industry 4.0 , pengembangan Bimbingan Konseling Islam dihadapkan pada berbagai tantangan dan peluang. Kiprah dan kontribusi Bimbingan Konseling Islam dalam menjawab tantangan dan mengelola peluang akan menunjukkan eksistensinya di Masyarakat. Sejumlah tantangan dan peluang yang dihadapi meliputi berbagai strategi dan teknik pelayanan Bimbingan Konseling Islam. Pelayanan Bimbingan Konseling Islam yang dilakukan oleh konselor Islam harus dapat merebut kepercayaan publik (public trust) melalui peningkatan pelayanan Bimbingan Konseling Islam yang tepat. Hasil yang diharapkan dari pelayanan adalah pengentasan masalah individu, kemandirian dan kemampuan manusia Indonesia untuk mampu berkompetisi dalam masyarakat global sehingga akan tetap eksis dalam kehidupannya sepanjang masa. Masa depan yang selalu berkembang menuntut pelayanan Bimbingan Konseling Islam untuk selalu menyesuaikan diri dengan kebutuhan, keinginan, permasalahan pihak yang dilayani dan juga tuntutan lingkungan masyarakat.

\section{B. Peluang Strategi Bimbingan Konseling Islam}

Dalam menghadapi era revolusi industri 4.0, yang diidentikkan dengan kemajuan Teknologi Informasi dan internet untuk segala (Internet of Things/IoT), mempengaruhi gaya hidup individu dalam berkomunikasi, interaksi, dan memenuhi kebutuhan segala hajat hidupnya, sehingga semua orang harus dapat menyesuaikan dan mampu menyikapi perubahan peradaban ini. Tidak terkecuali profesi bimbingan konseling Islam dengan merancang strategi atau teknik untuk bisa tetap eksis dan berkontribusi pada masyarakat global, oleh karena itu ada 2 (dua) strategi bimbingan konseling Islam yang ditawarkan untuk melakukan layanannya pada konseli, yaitu antara lain;

1. BKI Berbasis Teknologi Informasi (information technology)

Teknologi informasi diartikan sebagai perpaduan antara teknologi komputer dan telekomunikasi dengan teknologi lainnya seperti perangkat keras, perangkat lunak, database, teknologi jaringan, dan peralatan telekomunikasi lainnya. Sedangkan menurut Martin, Teknologi informasi tidak hanya terbatas pada teknologi komputer (perangkat keras dan perangkat lunak) yang digunakan untuk memproses dan menyampaikan 
informasi, melainkan juga mencakup teknologi komunikasi untuk mengirimkan informasi.

Sehingga dapat disumpulkan bahwa teknologi informasi (TI), ialah teknologi yang digunakan untuk menyampaikan informasi melalui teknologi telekomunikasi dan peralatan komunikasi sehingga pesan yang disampaikan dapat diterima dan dipahami. Perkembangan TI di Indonesia saat ini sangat berkembang pesat bersamaan dengan penemuan dan pengembangan Ilmu Pengetahuan dalam bidang Informasi dan Komunikasi, sehingga mampu menciptakan alat-alat komunikasi yang sangat mendukung Perkembangan teknologi informasi, contohnya saja seperti komunikasi searah maupun dua arah. Selain itu dengan adanya internet di Indonesia sangat memudahkan kita dalam memenuhi kebutuhan-kebutuhan dalam teknologi informasi yang berbasis Internet. Salah satu penggunaan teknologi tersebut adalah bidang Bimbingan Konseling. ${ }^{2}$

Perkembangan ilmu pengetahuan dan teknologi, meningkatnya mobilitas penduduk dari suatu tempat ke tempat lain, dan bertambahnya jumlah imigran dan pekerja dari suatu negara ke negara lain sangat erat kaitannya dengan konteks merentas budaya. Demikian juga dengan mudahnya akses orang terhadap jaringan internet melahirkan kecenderungan baru dalam konseling/ penyuluhan yang dikenal dengan Cyber Counseling, yang pada saat sekarang semakin populer. Komunikasi konselor dengan klien menggunakan e-mail, bisa juga secara interaktif (online) dan melibatkan lebih dari dua orang. Proses konseling seperti ini sangat kental dengan isu-isu merentas budaya, dan sangat mungkin akan berkembang dalam pelaksanaan konseling/ penyuluhan di Indonesia. ${ }^{3}$

Selain adanya TI menjadi strategi dalam layanan bimbingan konseling Islam, disisi lain juga dapat menjadi alternatif model konseling yang syar'i karena aspek etika dan menghormati konseli yang berlainan jenis kelamin dengan konselornya, serta bukan muhrimnya. Demi menghargai aqidahnya dan memberikan kebebasan wawancara atau komunikasi.

Menurut Prayitno dan Erman Amti, bimbingan adalah proses pemberian bantuan yang dilakukan oleh orang yang ahli kepada seseorang atau beberapa orang individu, baik anak-anak, remaja, maupun dewasa agar orang-orang yang dibimbing dapat mengembangkan kemampuan dirinya sendiri dan mandiri, dengan memanfaatkan kekuatan individu dan sarana

\footnotetext{
${ }^{1}$ Sri Maharsi . Pengaruh Perkembangan Teknologi Informasi Terhadap Bidang Akuntansi Manajemen. Jurnal Akuntansi dan Keuangan. Vol. 2, No. 2,

${ }^{2}$ Izeere, Teknologi Informasi, (online). http://izeere.blogspot.co.id/2011/09/teknologiinformasi.html. Diakses 10 September 2015.

3Sulistyorini. "Urgensi Penggunaan Teknologi dalam BK". (online). http://ninishoes.blogspot.co.id/2012/06/makalah-2.html. Diakses tanggal 10 Sepetember 2015.
} 
yang ada dan dapat dikembangkan berdasarkan norma-norma yang berlaku. ${ }^{4}$ Beberapa manfaat TI dalam Bimbingan Konseling Islam yakni, mempermudah konselor dalam menyusun, mencari dan mengolah data, menjaga kerahasiaan suatu data, karena dengan teknologi memungkinkan untuk menguncinya dan tidak sembarang orang dapat mengaksesnya, membantu individu maupun kelompok untuk dapat berkomunikasi dengan lebih mudah dan relatif murah dalam pelaksanaan konseling, memberikan kesempatan kepada individu untuk berkomunikasi lebih baik dengan menggunakan informasi yang mereka terima tanpa bertemu secara langsung (E-Counseling/ video conferenceng), dan menjadikan teknologi informasi sebagai alat dalam suatu program kegiatan, sehingga kegiatan tersebut lebih teratur dan terstruktur.

Salah satu penerapan teknologi informasi dalam Bimbingan Konseling Islam diantaranya pada penyelenggaraan dukungan sistem. Dukungan sistem dapat berupa sarana-prasarana, sistem pendidikan, sistem pengajaran, visi-misi sekolah dan lain sebagainya. Berbicara sarana-prasarana, memasuki dunia globalisasi dengan pesatnya teknologi dan luasnya informasi menuntut dunia Bimbingan Konseling Islam untuk menyesuaikan dengan lingkungannya agar memenuhi kebutuhan masyarakat luas.

2. Bimbingan Konseling Islam Berbasis Nilai-Nilai Budaya Indonesia

Ilmu pengetahuan dan teknologi haruslah diarahkan kepada kehidupan bermoral manusia. Oleh karena itu esensi nilai dalam masyarakat global menjadi amat penting, dalam kondisi manusia menghadapi ketidakpastian (uncertainty) dan bahkan kesemrawutan (chaos) yang bisa membuat nilai-nilai rujukan yang ada menjadi amat rentan terhadap pengaruh nilai-nilai baru yang dangkal dan instrumental. Disinilah manusia perlu belajar memahami dan memaknai nilai agar nilai rujukan yang diikutinya tidak semata-mata nilai transformasi kultural tetapi dimaknai secara kontekstual.

Bimbingan Konseling Islam merupakan kegiatan yang esensial di dalam setiap kehidupan masyarakat modern di era globalisasi yang penuh dengan risiko dalam kehidupannya. Penyuluhan tidak mungkin terjadi dan terlepas dari kehidupan bermasyarakat dimana individu-individu yang dilayani hidup dalam lingkungan masyarakat yang berbudaya. Oleh karena itu setiap masyarakat mempunyai kebudayaannya, maka penyuluhan merupakan suatu kegiatan budaya, karena dalam proses penyuluhan akan terjadi perjumpaan budaya antara budaya konselor dan budaya konseli.

Budaya Indonesia dihasilkan dari konfigurasi budaya suku bangsa yang beraneka ragam. Setiap suku bangsa memiliki budaya dan sub-sub budaya. Dalam budaya suku bangsa dan sub budaya suku bangsa terkandung nilai-

${ }^{4}$ Priyatno dan Erman Amti. Dasar-dasar Bimbingan dan Konseling. (Jakarta: Rineka Cipta. 1994), h. 99 
nilai budaya yang unik dan khas. Nilai-nilai tersebut dianut dan dijadikan norma pribadi (self norm) oleh individu pendukungnya dalam bertingkah laku. Sasaran layanan bimbingan penyuluhan adalah prilaku individu yang dipengaruhi oleh nilai -nilai budayanya. Karena itu, layanan bimbingan konseling Islam sudah sepatutnya mempertimbangkan nilai-nilai budaya.

Bimbingan Konseling Islam diharapkan dapat menunjukkan pada konseli tentang nilai-nilai kebudayaan dimana ia berada untuk ditaati dan diamalkan, termasuk kebudayaan Islam yang dibawah dan diajarkan oleh para ulama' di Indonesia seperti Wali Songo, yang terkenal dalam mengembangkan Islam di Pulau Jawa adalah Sunan Gresik, Sunan Ampel, Sunan Bonang, Sunan Drajat, Sunan Kalijaga, Sunan Giri, Sunan Kudus, Sunan Muria, dan Sunan Gunung Jati. Keteladanan Wali Songo mengandung nilai-nilai ajaran yang terdapat dalam manuskrip-manuskrip (kitab-kitab) karya-karyanya, artefak-artefak, seni dan syair- syair lagu yang mengandung pesan-pesan ketauhidan, sikap menyembah Allah SWT dan tidak menyekutukannya.

Banyak penelitian tentang nilai-nilai Wali Songo, misalnya penelitian Gusjigang merupakan falsafah budaya lokal ajaran Sunan Kudus yang berpengaruh pada masyarakat Kudus. Seiring perkembangan waktu banyak remaja Kudus yang tidak mengetahui arti dan makna Gusjigang. Muncul inisiatif dari pengelola pondok Pesantren Entrepreneur Al Mawaddah Kudus yang berusaha melestarikan nilai karakter Gusjigang. Metode penelitian yang digunakan adalah kualitatif dengan teknik analisis data menggunakan analisis interaktif meliputi reduksi data, sajian data, penarikan kesimpulan dan verifikasi. Hasil penelitian menunjukkan bahwa: (1) Gusjigang falsafah dari spirit Sunan Kudus yang mengandung nilai karakter. Nilai karakter yang terkandung didalamnya, meliputi Gus (bagus) meliputi jujur, toleransi, disiplin, peduli sosial, dan tanggung jawab. Ji (ngaji) meliputi religius, rasa ingin tahu, gemar membaca. Gang (dagang) meliputi kerja keras, kreatif, dan mandiri. ${ }^{5}$

Penelitian nilai-nilai Lontar Yusuf, Kitab Lontar Yusuf sebagaimana yang ada di Banyuwangi berisi kisah hidup dari nabi yusuf dari usia 12 tahun, ketika ia bermimpi matahari, bulan, dan 11 bintang bersujud kepadanya, hingga dia naik tahta sebagai raja Mesir setelah penjelasannya tentang mimpi sang Fir'aun. Lontar Yusuf yang disinyalir ditulis oleh seorang Wali pada Abad XVI masa akulturasi budaya Hindu ke Islam dengan ditandainya pernikahan Dewi Sekardadu Putri Prabu Menak Sembuyu dengan Syeh Maulana Iskak. Isi Lontar Yusuf Lontar Yusuf terdiri dari 4 pupuh dan 581 bait, setiap bait dalam pupuh-pupuh Lontar Yusuf

${ }^{5}$ Muharromiyati.(2016). "Pewarisan Nilai Falsafah Budaya Lokal Gusjigang sebagai Modal Sosial di Pondok Pesantren Entrepreneur Al Mawaddah Kudus", Journal Educational of Studis. 
memiliki kandungan makna sebagai berikut : Pupuh Kasmaran (1-10) Pengantar, dan tentang Kejahatan Saudara Nabi Yusuf pada dirinya, serta kebaikan-kebaikan Yusuf saat menghadapi masalah (60-69). Pupuh Durmo (1-5) tentang Kemuliaan lima Binatang yang kelak masuk Surga dan kecantikan ratu jeleka yang terpesona ketampanan Yusuf dalam mimpinya, Pupuh Pangkur (1-42) tentang Ketauhidan membentuk pribadi sehat, Pupuh Sinom (1-46) tentang kemuliaan hati, dan kepandaian Yusuf dalam tafsir mimpi untuk memecahkan berbagai persoalan hidup hingga Yusuf jadi Raja Mesir. ${ }^{6}$

Banyak sekali pesan leluhur sangat berarti dan sebagai anutan bagi generasi penerus Bangsa, daripada mereka belajar dan meneladani gaya hidup dari Barat yang tentu beda latar belakang nilai budayanya. Nilai-nilai keteladanan tokoh Nasional seperti Ki Hajar Dewantara, Raden Ajeng Kartini, dan seterusnya, sangat penting untuk dijadikan dasar teori layanan Bimbingan Konseling Islam di era revolusi Industri 4.0.

Bimbingan Konseling Islam harus memberi wahana kepada individu sasaran layanan sebagai generasi muda penerus bangsa untuk mengenali dan mengembangkan kebudayaan sebagai sistem nilai, sistem pengetahuan, dan sistem perilaku bersama melalui olahpikir, olahrasa, olahkarsa, dan olahraga. Kebudayaan sebagai sistem nilai, sistem pengetahuan, dan sistem perilaku ini secara keseluruhan membentuk lingkungan sosial yang dapat menentukan apakah disposisi karakter seseorang berkembang menjadi lebih baik atau lebih buruk. Penyuluhan harus dirancang dengan tetap mengunggulkan derajat dan martabat manusiawi generasi muda penerus bangsa agar menjadi bangsa yang bertaqwa dan mampu beradaptasi dalam perkembangan zaman yang penuh risiko.

Penyuluhan membantu individu (konseli) membangun sistem nilai budaya bangsa Indonesia untuk dapat menjadi manusia yang kembali fitrah (agama Islam) sehingga mampu bersaing dan bersanding dalam era revolusi Industri. Sistem nilai budaya terdiri dari konsepsi-konsepsi, yang hidup dalam alam pikiran sebagian besar warga masyarakat, mengenai hal-hal yang harus mereka anggap amat bernilai dalam hidup. Karena itu, sistem nilai budaya biasanya berfungsi sebagai pedoman bagi kelakukan manusia.

Meskipun masyarakat Indonesia memasuki masyarakat milenial, harus berpegang teguh dengan sistem nilai budaya bangsa Indonesia yang telah berakar dalam alam jiwa manusia yaitu watak serta peradaban bangsa yang bermartabat. Menurut Kluckhohn, bahwa semua sistem nilai budaya dalam kebudayaan di dunia itu sebenarnya mengenai lima masalah pokok dalam kehidupan manusia, yaitu masalah:

a. Hakikat dari hidup manusia.

${ }^{6}$ Rofiq Arif Ainur. (2016). Kajian Nilai-Nilai Budaya Using Banyuwangi dalam Kitab Lontar Yusuf dan Apilkasinya pada Konseling. UM.Malang: Disertasi tidak diterbitkan. 
b. Hakikat dari karya manusia.

c. Hakikat dari kehidupan manusia dalam ruang waktu.

d. Hakikat dari hubungan manusia dengan alam sekitarnya.

e. Hakikat dari hubungan manusia dengan sesamanya.

Konselor melalui pelayanan bimbingan konseling Islam membantu individu (konseli) untuk membangun sistem nilai budaya yang berkaitan dengan permasalahan kehidupan manusia, karya manusia, kehidupan manusia dalam ruang waktu, hubungan manusia dengan alam sekitar, hubungan manusia dengan sesamanya, dan hubungan manusia dengan Maha Pencipta. Lima masalah pokok yang menentukan orientasi nilai budaya tersebut, dapat ditanamkan dan dikembangkan nilai-nilai kebudayaan yang bersumber dari budaya, agama, dan Pancasila yang melekat pada kehidupan bangsa menjadi basis dalam pelayanan bimbingan konseling Islam seperti pandangan hidup, kejujuran, kebaikan, estetika, dan berbagai nilai lain yang dipandang berharga dalam kehidupan. Konselor membantu individu (konseli) untuk menanamkan dan mengembangkan sistem nilai dan norma yang menjadi patokan untuk sikap mental dan perilaku yang benar, baik, dan pantas serta menjauhi hal-hal yang salah, buruk, dan tidak pantas. Disinilah bimbingan konseling Islam dalam membudayakan individu yang akan menjadikan mansuia Indonesia yang mampu berpikir, bersikap, dan bertindak sehari-hari maupun dalam menghadapi permasalahan-permasalahan dalam kehidupannya. Sistem nilai ini harus dibangun secara holistik sehingga menjadi keutuhan dalam kehidupan manusia dalam masyarakat yang penuh risiko,yaitu masyarakat modern dan masyarakat globalisasi.

\section{Tantangan Bimbingan Konseling Islam}

Persaingan antar profesi dalam era revolusi Industri 4.0, menuntut penguasaan dan pengembangan ilmu pengetahuan dan teknologi dalam menjalankan profesi. Oleh sebab itu, semua profesi berlomba-lomba untuk menjadikan ilmu pengetahuan dan teknologi sebagai dasar profesinya. Profesi konselor Islam menjadi pilihan yang sangat menarik karena akan membantu kehidupan manusia menjadi lebih efektif dalam kehidupan keseharian berdasarkan norma-norma yang berlaku. Hal ini tentunya profesi konselor akan menarik putra-putra terbaik dari bangsa untuk menjadi konselor masa depan. Apabila salah satu syarat suatu profesi dalam era globalisasi relatif telah dapat dipenuhi, tugas dan tanggung jawab pembinaan akademik merupakan tugas selanjutnya yang tidak kurang berat tanggung jawabnya, bahkan yang paling menentukan. Pembinaan profesi konselor dalam rangka untuk meningkatkan keunggulan dan daya saing era globalisasi merupakan keniscayaan untuk meningkatkan mutu pelayanan bimbingan penyuluhan Islam, sehingga profesi konselor Islam tetap terhormat dan bermartabat dalam persaingan antar profesi dan persaingan antar Bangsa. 
Berbagai upaya pengembangan profesi konselor Islam/ Bimbingan Konsleing Islam yang mengarah pada terwujudnya standarisasi profesi konselor. Kegiatan-kegiatan itu dapat berupa program-program pengembangan yang secara langsung diimplementasikan berdasarkan otoritas dan kebijakan yang dimiliki oleh pihak-pihak yang berwenang, kolaborasi dengan stakeholders dan pihak-pihak pengguna layanan profesi konselor, validasi standarisasi profesi yang berbasis kebutuhan lapangan baik secara nasional maupun internasional, dan kredensial. Upaya dan tindak lanjut tersebut dilakukan baik oleh Perguruan Tinggi penghasil konselor, Ditjen Kemenristekdikti, Kemendikbud, Kemenag, maupun asosiasi profesi konselor Islam, dalam porsi kewenangan dan tanggung jawab masing-masing.

Pengembangan dan inovasi-inovasi dalam rangka mengokohkan dan mempromosikan identitas, kelayakan dan akuntabilitas profesi konselor secara nasional maupun internasional sangat penting dan harus dilakukan oleh konselor dalam menjalankan profesinya. Mengapa harus dilakukan? Karena bimbingan konseling Islam merupakan profesi yang dinamis, selalu berkembang, dan menyenangkan, yang berhubungan dengan tragedi manusia dan kemungkinan dalam cara yang intensif, personal dan perhatian. Profesi konseling/ penyuluhan merupakan profesi yang didedikasikan terhadap pencegahan, perkembangan, eskplorasi, pemberdayaan, perubahan dan remediasi di dunia yang semakin kompleks. Menjadi konselor adalah sebuah proses seumur hidup. Selain itu, konselor harus belajar dan terus berusaha mendapatkan informasi terbaru mengenai peraturan pemerintah terkait dengan profesinya dan pendidikan.

Konselor era revolusi industri 4.0 harus memenuhi pelatihan dan kredensial minimal meliputi tiga aktivitas,yaitu (a) lulus dari program pendidikan yang terakreditasi, (b) memperoleh sertifikat atau ijazah, dan (c) memperoleh lisensi (izin praktik). Semua calon konselor dilatih melalui program pendidikan yang berlandaskan kompetensi dan standar profesi tertentu. Selain tenaga profesional memperoleh gelar untuk konseling atau bidang terkait, konselor juga berusaha memperoleh lisensi (izin praktik) setelah pendidikan dan pelatihan selesai. Lisensi (izin praktik) adalah penetapan kredensial secara legislatif yang dianggap jauh lebih bernilai daripada sertifikat,karena tidak hanya mengatur gelar, namun juga praktik profesinya.

Identitas profesional konselor akan dibuktikan oleh sertifikasi, akreditasi, dan lisensi. Sertifikat profesi yaitu pengakuan bahwa seseorang telah memiliki kompetensi untuk melaksanakan pelayanan konseling setelah lulus uji kompetensi yang diselenggarakan oleh lembaga pendidikan profesi konseling yang terakreditasi atau lembaga sertifikasi. Akreditasi memberikan derajat penilaian terhadap kondisi yang dimiliki oleh satuan pengembang dan/atau pelaksana konseling seperti jurusan/program studi bimbingan konseling Islam/ bimbingan penyuluhan Islam di Perguruan Tinggi yang dinyatakan kelayakan 
program satuan pendidikan. Lisensi memberikan izin kepada konselor untuk melaksanakan praktik pelayanan konseling/ penyuluhan.

\section{Kesimpulan}

Sejumlah tantangan dan peluang dihadapi oleh Program Studi BKI/ Bimbingan Konseling Islam di era revolusi Industri 4.0 adalah, Program Studi BKI perlu melakukan penguatan internal dan pengembangan kerjasama dengan pihak lain. Sebagai lembaga yang akan menghasilkan konselor sosial -Islam dan pendidikan yang memiliki kapasitas diri yang unggul, Program Studi BKI/BPI dapat meningkatkan kualitas layanan bimbingan konseling Islam dengan berbagai strategi dan teknik sesuai kebutuhan konseli era revolusi Industri 4.0. Kompetensi konselor Islam juga harus ditingkatkan, baik kompetensi psikologi, pedagogi, dan komptensi kepribadian (empati, kongruensi, dan dapat memberikan penghargaan) pada diri konseli.

\section{Daftar Pustaka}

Ahmad Mubarok, Al-Irsyad an Nafsy. (2002). Konseling Agama Teori dan Kasus .Yogyakarta: Fajar Pustaka Baru.

Izeere, Teknologi Informasi, (online). http://izeere.blogspot.co.id/2011/09/teknologi-informasi.html.

Diakses 10 September 2015.

Koentjaraningrat.(2000). Kebudayaan Mentalitas dan Pembangunan. Jakarta: Kompas Gramedia.

Muharromiyati.(2016). Pewarisan Nilai Falsafah Budaya Lokal Gusjigang sebagai Modal Sosial di Pondok Pesantren Entrepreneur Al Mawaddah Kudus", Journal Educational of Studis.

Novita Wahyu Nugraeni, Pemanfaatan Teknologi Informasi untuk Layanan BK Komprehensif.http://novitawahyunugraeny.blogs.uny.ac.id/2015/09/2 6/pemanfaatan-teknologi-informasi-untuk-layanan-program-bkkomprehensif/. Diakses 9 April 2018.

Priyatno dan Erman Amti. 1994. Dasar-dasar Bimbingan dan Konseling. Jakarta: Rineka Cipta.

Rofiq Arif Ainur. (2016). Kajian Nilai-Nilai Budaya Using Banyuwangi dalam Kitab Lontar Yusuf dan Apilkasinya pada Konseling. UM.Malang: Disertasi tidak diterbitkan.

Sri Maharsi . Pengaruh Perkembangan Teknologi Informasi Terhadap Bidang Akuntansi Manajemen. Jurnal Akuntansi dan Keuangan. Vol. 2, No. 2, (online). http://stppyogyakarta.ac.id/artikel-ilmiah-dan-ilmiahpopuler/artikel-ilmiah-dan-populer-tahun-2013. Diakses 11 September 2015. 
Sulistyorini. Urgensi Penggunaan Teknologi dalam BK. (online). http://ninishoes.blogspot.co.id/2012/06/makalah-2.html. Diakses tanggal 10 Sepetember 2015.

Van L. King.(2008). Assessing the effectiveness of an Internet-based videoconferencing platform for delivering intensified substance abuse counseling". Journal of substance abusetreatment.

Vacc,N.A., \& Loesch,L.C.(2000). Professional Orientation to Counseling. Philadelphia,PA: Brunner-Rotledhe. 